Eksergi, Vol 17, No. 2. 2020

ISSN: $1410-394 \mathrm{X}$

\title{
Influence of Particle Size and Chemical Activation on Rice Husk Biochar as Slow Release Fertilizer
}

\author{
Natasha Amelia Rigitha Akhwan*and Avido Yuliestyan \\ Chemical Engineering Department, Faculty of Industry Engineering, UPN "Veteran" Yogyakarta
}

Jln. SWK 104 (Lingkar Utara) Condongcatur, Yogyakarta 55283, Indonesia

\section{Artikel histori : \\ Diterima 10 September 2020 Diterima dalam revisi 26 Oktober 2020 Diterima 29 Oktober 2020 Online 31 Oktober 2020}

\begin{abstract}
ABSTRAK: Nitrogen, Fosfat, dan Kalium adalah elemen nutrisi penting yang terkandung dalam pupuk untuk tanaman tetapi kehadiran mereka di tanah dapat dengan mudah larut tercuci oleh air hujan. Biochar, berasal dari sekam beras dengan kemampuan menyerap tinggi, mungkin dapat digunakan untuk menghambat pelepasan nutrisi tersebut. Penelitian ini bertujuan untuk menyelidiki pengaruh ukuran biochar dan aktivasi kimia $\mathrm{HCl}$. Biochar, yang telah dipirolisis, diayak dan disaring untuk mendapatkan bubuk dengan ukuran rata-rata setara dengan 0,2735 mm;0,4485 $\mathrm{mm} ; 0.725 \mathrm{~mm}$; dan 0,925 mm. Ukuran optimal biochar kemudian diaktifkan menggunakan $\mathrm{HCl}$ dengan konsentrasi 3\%; 9\%; dan 15\%. Proses pencucian pupuk, yang bertujuan untuk meniru pencucian air hujan, dilakukan dengan menuangkan air setiap hari pada kolom pasir dengan adanya biochar jenuh dengan pupuk berwarna. Solusi yang diperoleh kemudian dianalisis menggunakan Spektrofotometer. Hasil penelitian menunjukkan bahwa perkiraan waktu rilis untuk kasus dengan tidak adanya biochar adalah 36 hari, berbeda dengan 55 hari untuk kasus dengan adanya biochar.
\end{abstract}

Kata Kunci: biochar, spektrofotometer, aktivator kimia, pupuk lepas-lambat, pencucian

\begin{abstract}
Nitrogen, Phosphate, and Potassium are important nutritional elements contained in the fertilizers for plants but their presence in the soil could be easily wash out by rain water. Biochar, originated from rice husks with a high absorbance ability, might be able to be used to inhibit the release of those nutrients. This research aims to investigate the influence of biochar size and the HCl chemical activation. Biochar, which has been pyrolyzed, was ground and sieved to obtain powder with the size average equivalent to $0.2735 \mathrm{~mm}$; $0.4485 \mathrm{~mm} ; 0.725 \mathrm{~mm}$; and $0.925 \mathrm{~mm}$. The optimized biochar size were opted for later being activated using $\mathrm{HCl}$ with a concentration of 3\%; 9\%; and 15\%. The leaching process of fertilizer, aiming to imitate the rain water washing, was performed by pouring water on a daily basis on a sand column with the presence of biochar saturated with colorized fertilizer. The obtained solution were then characterized using Spectrophotometer. The results show that the estimated release time for the case with the absence of biochar is 36 days, in contrast to 55 days for the case with the presence of biochar.
\end{abstract}

Keywords: biochar, spectrophotometer, chemical activator, slow-release fertilizer, leaching

\section{Introduction}

Agricultural land conditions in Indonesia might be considered in on a poor health due to the excessive use of inorganic fertilizers, possibly. Damaging the soil structure. For such case, Zhong et al (2018) states that combining biochar with inorganic fertilizers can not only increase the efficiency of using inorganic fertilizers but also improve soil environment and encourage plant growth, which shows great significance for the development of our agriculture. Biochar is thermally decomposed charcoal by pyrolysis process in the absence of oxygen. It could be originated from the agricultural waste such as wood, rice husks, oil palm shells, cocoa pod husks and other wastes. (Grycová et al., 2016).
Addition biochar to soil can affect physicochemical and biological processes such as adsorption and desorption, complexation/dissociation, oxidation/reduction and mobilization/immobilization that control mobility and availability of macro and micro nutrients for plants. (Glaser et al., 2015). Research from Ademiluyi (2012), activation of biochar material will affect specific surface area, pore structure, and surface chemical functional groups of specified porous carbon applications determined by acid pretreatment using $\mathrm{HCl}, \mathrm{H}_{2} \mathrm{SO}_{4}$, and $\mathrm{C}_{2} \mathrm{H}_{4} \mathrm{O}_{2}$ results in a significant reduction in bioadsorption. Biochar, is indicated to be used to inhibit the release of these nutrients by means of the fertilizer washing process, which aims to mimic the washing of rain water. (Indarto and Hartanto, 2019). The washing of rain water is in principle a leaching process of

*Corresponding Author:

Email: natasharigitha@gmail.com 
the fertilizer on biochar. Leaching process is defined as mass transfer of material into the solvent that initially penetrates the solid or get into the pore of the solid. One of factors that determines the value of mass transfer coefficient is the particle size. Value of mass transfer coefficient determine the speed of diffusion of a substance that is dissolved into a solvent.

The results of this research is expected not only to reduce the amount synthetic fertilizer used and wasted, so as to save operational costs but also to restore quality of agricultural land and improve environmental friendliness by slowing down the release of fertilizer saturated on a biochar. This research aims to investigate (1) the influence of rice husk biochar size by varying its average sizes of $0,2735 \mathrm{~mm} ; 0,4485 \mathrm{~mm} ; 0,725 \mathrm{~mm}$; and $0,925 \mathrm{~mm}$, and (2) the effect of chemical activation by using hydrochloric acid $(\mathrm{HCl})$ with a concentration of $3 \%, 9 \%, 15 \%$.

\section{Experimental Method}

\subsection{Materials}

Sand size -18 mesh +50 mesh, timee for activation is 24 hours at $110^{\circ} \mathrm{C}$, adsorption process takes 4 hours and 6 hours without stirring, adsorption temperature.

The material used in this research is fertilizer containing blue dye. The rice husk biochar which is made from rice husk with sand supporting material of a certain size, hydrochloric acid $(\mathrm{HCl})(3 \% ; 9 \% ; 15 \%)$, and aquades.

\subsection{Sample Preparation and Analysis}

\subsubsection{Biochar Saturation}

Initially biochar was grounded and sieved to obtain the average size of $0.925 ; 0.725 ; 0.4485$ and $0.2785 \mathrm{~mm}$ for investigating the influence of size. Saturation was performed in a beaker by means of soaking $2.5 \mathrm{gr}$ of biochar in $3.2 \mathrm{gr}$ of fertilizer for approximately 24 hours with the purpose of allowing fertilizer to saturate it. After a day, the saturated biochar was separated from the remaining fertilizer, if any. Similar procedure was done for the case of chemical activation, except for the used size of $0.725 \mathrm{~mm}$ and chemically activated using $3 \% ; 9 \%$ and $15 \%$ of $\mathrm{HCl}$.

\subsubsection{Leaching Process}

Prior to leaching process, a set up was prepared to imitate the rainfall washing. The set up consists of a PVC pipe with a dimension of $3 \times 30 \mathrm{~cm}$ (diameter $\times$ height), installed vertically to a structure. Its top end was set open, while the other end was sealed with a wiremesh of 100 mesh, connected to a container. This leaching experiment was initially designed and reported by Chen et al., 2018. Inside the pipe, sand with the size range of +18 mesh to -50 mesh were inserted prior to putting the biochar to provide structure as such disallow small biochar particle to being wash out and block the mesh.

To simulate the rainfall, $100 \mathrm{ml}$ of distilled water was added slowly every 24 hours. Fertilizer content in leach solution was measured by spectrophotometry with a wavelength $450 \mathrm{~nm}$ in absorbance value.

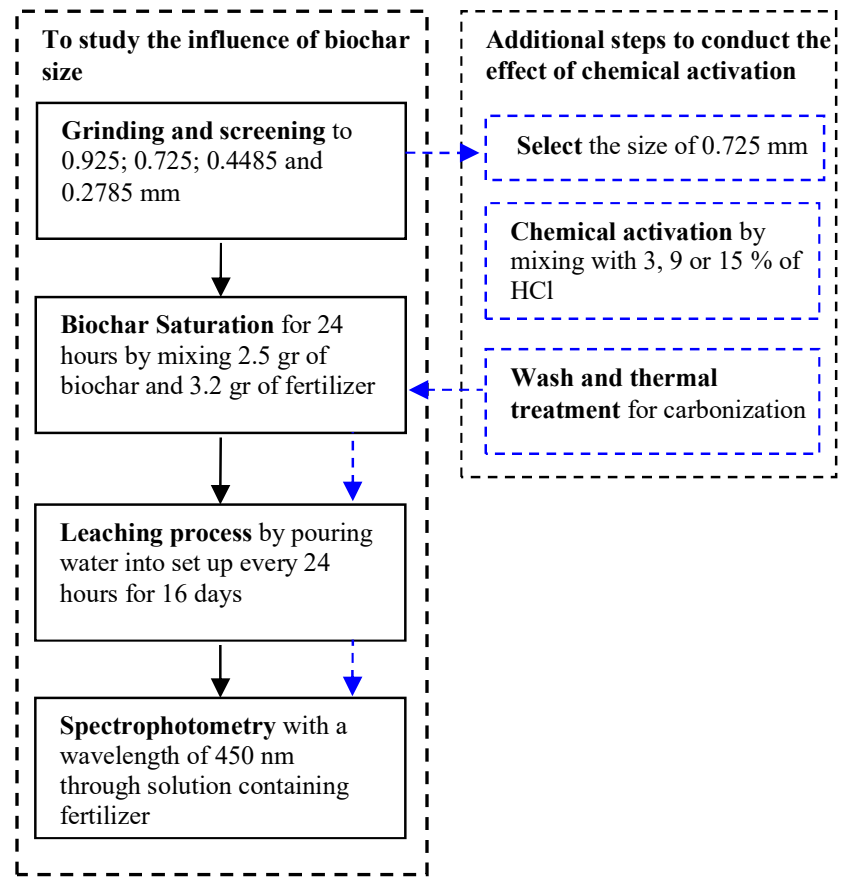

Figure 1. Experimental Procedure Flow Diagram of Leaching Process

\section{Result and Discussion}

\subsection{Qualitative Assessment and Standard Curve for Quantitative Approach}

In this research, the analysis of the effect of rice husk biochar size and the influence of chemical activation on the release of fertilizer has been studied. The experiment consisted of two steps of processes which were the fertilizer saturation and leaching process. The goals were achieved by determining the amount of fertilizer with embedded colorant being released upon several sequential solvent washing processes during 16 days.

Qualitative assessment on the water, used as the leaching solution for washing, has shown such difference in their color, as presented in Figure 2. For instance, the "first day" leaching samples in the presence of biochar produced a lighter blue color as compared to the samples without biochar showing a darker blue. On the second and subsequent days, all leaching sample produced a clearer color after several washings.

Aiming to provide further quantitative information, a standard curve was developed by plotting the absorbance data in $y$-axis against the concentration data represented as fertilizer/water volumetric ratio in $\mathrm{x}$-axis, as shown in Figure 3. In this sense, concentration data of released fertilizer in the leaching solution could be easily converted by utilizing this curve. 


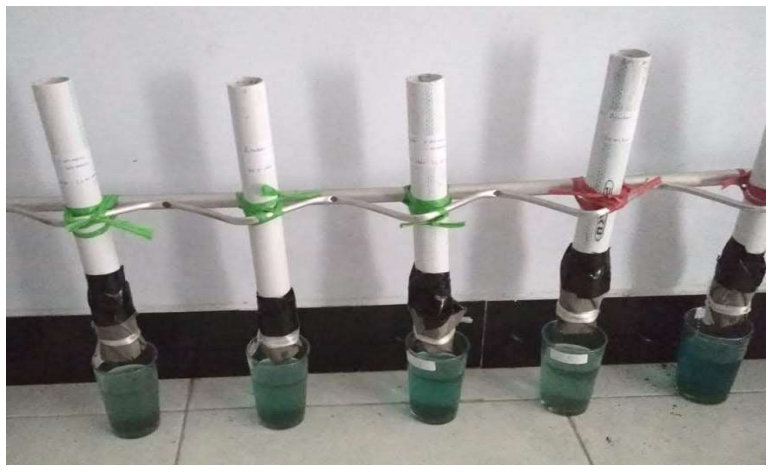

(a)

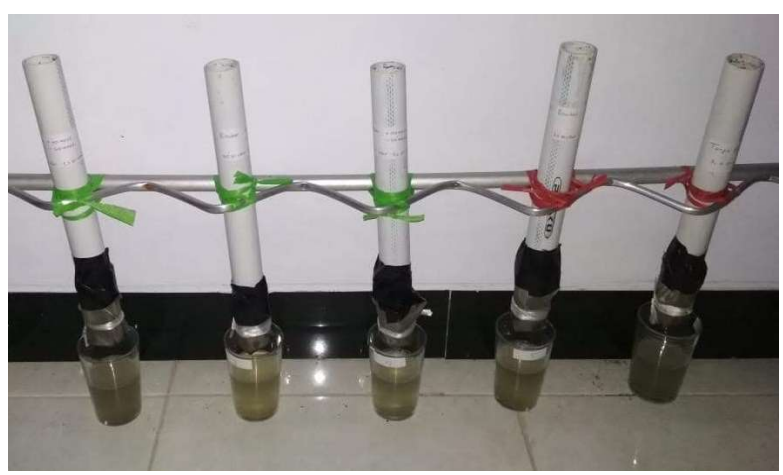

(b)

Figure 2. Qualitative Assessment on the Leaching Solution on : a) the First Day (a) and (b) the $16^{\text {th }}$ day

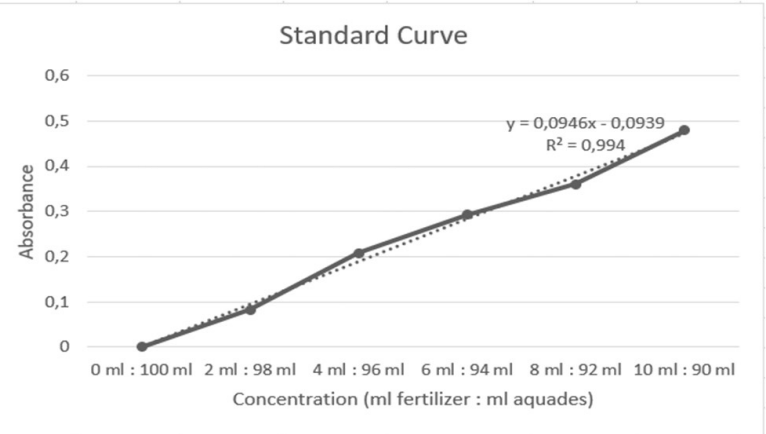

Figure 3. Standard Curve, Presenting the Absorbance vs Concentration (Fertilizer : Distilled Water ratio)

\subsection{The Influence of Biochar Size}

Table 1 presents the absorbance data of leaching solution passing through various sizes of biochar, which are 0.925 $\mathrm{mm} ; 0.725 \mathrm{~mm} ; 0.4485 \mathrm{~mm}$ and $0.2735 \mathrm{~mm}$, and the sample without the presence of biochar.
Tabel 1. Absorbance Data of Solution Passing through Saturated Biochar on its Various Size for 16 Day

\begin{tabular}{cccccc}
\hline Day & $\begin{array}{c}\text { Without } \\
\text { Biochar }\end{array}$ & $\begin{array}{c}\mathbf{0 , 9 2 5} \\
\mathbf{m m}\end{array}$ & $\begin{array}{c}\mathbf{0 , 7 2 5} \\
\mathbf{m m}\end{array}$ & $\begin{array}{c}\mathbf{0 , 4 4 8 5} \\
\mathbf{m m}\end{array}$ & $\begin{array}{c}\mathbf{0 , 2 7 3 5} \\
\mathbf{m m}\end{array}$ \\
\hline 1 & 0,318 & 0,134 & 0,156 & 0,0955 & 0,055 \\
2 & 0,166 & 0,096 & 0,054 & 0,051 & 0,038 \\
3 & 0,135 & 0,084 & 0,043 & 0,038 & 0,037 \\
4 & 0,040 & 0,041 & 0,038 & 0,037 & 0,035 \\
5 & 0,035 & 0,037 & 0,034 & 0,030 & 0,034 \\
6 & 0,030 & 0,033 & 0,028 & 0,027 & 0,031 \\
10 & 0,024 & 0,026 & 0,026 & 0,022 & 0,028 \\
13 & 0,017 & 0,026 & 0,025 & 0,024 & 0,027 \\
16 & 0,008 & 0,015 & 0,023 & 0,024 & 0,019 \\
\hline
\end{tabular}

After having the first washing, the presence of biochar with the size of $0,925 \mathrm{~mm}$ is able to inhibit the fertilizer release as much as 55,32\% as compared to the sample without biochar. This percentage is obtained based on the fact that the absorbance is proportional to the concentration, hence such decrease could be directly observed. Additionally, similar trend of inhibiting the release of fertilizer is also shown in the case of biochar with the smallest size of 0,2735 , showing as much as $82,71 \%$ referring to the same baseline. The reduction in size causes the surface area in biochar pores to become larger, as such is able to yield the higher pore volume to capture nutrients from inorganic fertilizers, or else, said to increase the ability of adsorption. This is in accordance with the discussion from (Fengfeng, 2015) which explains the biochar surface area is a key factor influencing adsorption capacity.

For biochar mass units, the smaller particle size, the greater surface area, and the clearer surface energy. Aiming to perceive better the evolution of desorption of the released nutrients, the converted absorbance data was plotted against time. Figure 4 shows the evolution of fertilizer concentration in the solution passing through saturated biochar on its various size for 16 day. It could be observed that the desorption is severe in the absence of biochar. However, the amount of fertilizer release slowed down over the time for all the cases, as shown by negative linear fitting line slope in logarithmic plotting. Smaller size of biochar tended to hold better the fertilizer than that of the one with the bigger size, as indicated by the degree of inclination.

The adsorption and desorption rate also depends on the surface area, the smaller the particles, the greater surface area will be, to cause the dispersion pathway to become narrow. Biochar adsorption capacity is not only related to the specific surface area, but also the pore volume, and pore size distribution ( $\mathrm{Li}$ et al., 2008). However, raw biochar material (without further treatment) has limited capacity to absorb pollutants due to less pore space (Tan et al., 2016). Based on this result, grounding the biochar, associated with providing more surface pore and volume, have shown positive result in holding the release of fertilizer. Additionally, chemical treatment might also be seen as an effective method for the same purpose of increasing the capacity. 


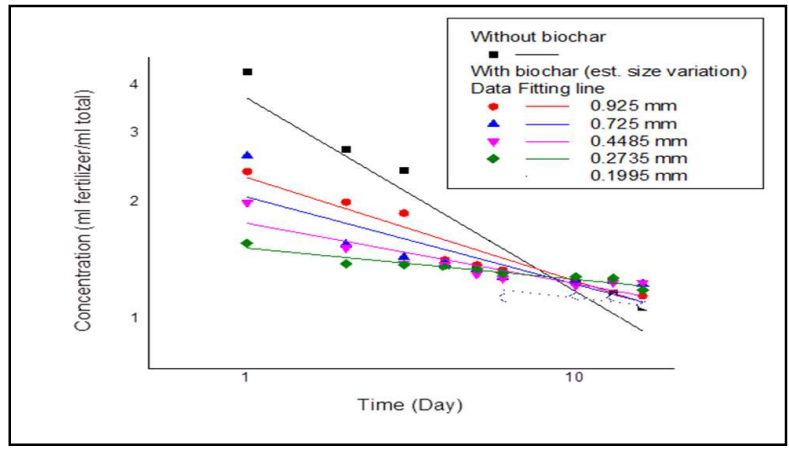

Figure 4. The Evolution of Fertilizer Concentration in the Solution Passing through Saturated Biochar on its Various Size for 16 Day.

\subsection{The Effect of Chemical Activation and its Concentration}

Chemical activation, where char is treated with chemicals, is the most common method for modifying surface functional groups, although the mechanism is not well understood. During this process, chemical agents dehydrate the sample, inhibit the formation of tar and volatile evolution compounds, and therefore increase the yield of the carbonization process. El-Hendawy 2009 said that the distribution of chemical agents in biochar before carbonization plays a key role in the development of porosity and functionality of the final product. Thermal treatment of the char functional group at high temperatures, fully carbonized organic matter, results in the formation of new nanopores, and a subsequent increase in surface area (Nair and Vinu 2016).

Table 2 presents absorbance data of solution passing through saturated biochar previously treated by chemical activation of 3,9 and $15 \%$ of $\mathrm{HCl}$. It is indeed there are differences between activated carbon prepared by various activation agents as well (Liqing Li, 2017).

Table 2. Absorbance Data of Solution Passing through Saturated Biochar Previously Treated by Chemical Activation of 3, 9 and $15 \%$ of $\mathrm{HCl}$

\begin{tabular}{|c|c|c|c|c|c|}
\hline \multirow[b]{2}{*}{ Day } & \multirow{2}{*}{$\begin{array}{l}\text { Without } \\
\text { Biochar }\end{array}$} & \multirow{2}{*}{$\begin{array}{c}\text { Physical } \\
\text { activation }\end{array}$} & \multicolumn{3}{|c|}{ Chemical activation } \\
\hline & & & $\begin{array}{l}\mathrm{HCl} \\
\mathbf{3 \%}\end{array}$ & $\begin{array}{l}\mathrm{HCl} \\
9 \%\end{array}$ & $\begin{array}{l}\mathrm{HCl} \\
15 \%\end{array}$ \\
\hline 1 & 0,318 & 0,156 & 0,059 & 0,032 & 0,043 \\
\hline 2 & 0,166 & 0,054 & 0,025 & 0,029 & 0,039 \\
\hline 3 & 0,135 & 0,043 & 0,022 & 0,025 & 0,020 \\
\hline 4 & 0,040 & 0,038 & 0,027 & 0,021 & 0,022 \\
\hline 5 & 0,035 & 0,034 & 0,030 & 0,027 & 0,028 \\
\hline 6 & 0,030 & 0,028 & 0,028 & 0,032 & 0,030 \\
\hline 10 & 0,024 & 0,026 & 0,023 & 0,021 & 0,026 \\
\hline 13 & 0,017 & 0,025 & 0,021 & 0,019 & 0,025 \\
\hline 16 & 0,008 & 0,023 & 0,014 & 0,028 & 0,023 \\
\hline
\end{tabular}

Biochar activated by $\mathrm{HCl}$ can inhibit fertilizer release, and obviously better perform than biochar without $\mathrm{HCl}$ activator or said merely being physically activated by heat. In the absence of biochar, the measured concentration on the first day is $4,354 \%$ in total volume. Whilst, the one with activators results a concentration of $1,616 \%$ which is better than the physically activated biochar with $2,642 \%$. Once activated, the chemical activators causes free radical interactions on the surface of carbon with atoms such as oxygen and nitrogen. Such that, activation with $\mathrm{HCl}$ is able to make biochar to release the attached component slower. According to Peiyua et al., 2016, $\mathrm{HCl}$ make the surface functional groups of chemically activated carbon reactive and affect the adsorption properties. The stronger the oxidizing acid, the more oxygen acid groups are on the surface of the biochar, which increases the hydrophilicity and carbon cation exchange capacity.

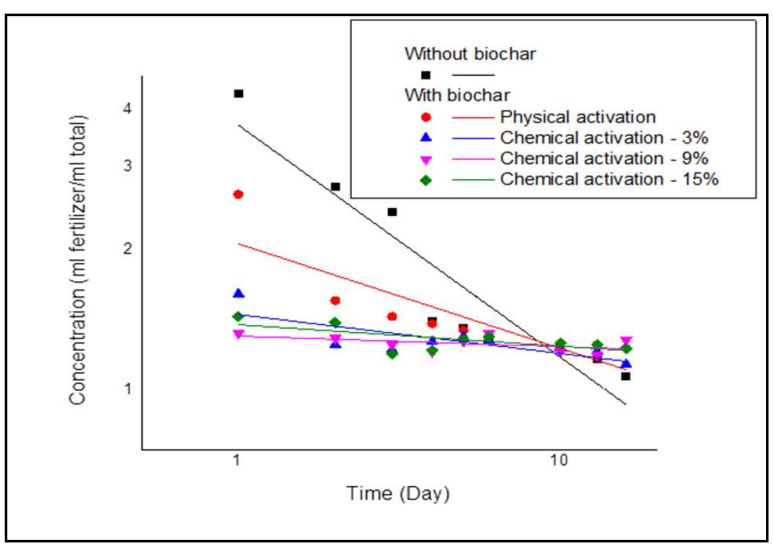

Figure 5. The Evolution of Fertilizer Concentration in the Solution Passing through Saturated Biochar Previously Treated by Chemical Activation of 3, 9 and $15 \%$ of $\mathrm{HCl}$

The data in Table 2 is converted into a logarithmic scale of concentration vs time, shown in Figure 5. Based on this figure, it is presented the slope with negative value is smaller for the case of biochar with chemical activation. This is also in accordance with results shown by Sizmur et al., 2017 where it explain that acid treatment provides a more oxygenated functional group on the surface of biochar and increases the potential of biochar to chemically bind positively charged compounds through specific adsorption. Chemical modification of biochar can increase the ability to absorb compounds by creating additional and abundant absorption sites in increased surface areas, making biochar surfaces more conducive to electrostatic attraction, surface complexation, and / or surface precipitation, and allows greater absorption affinity through greater interaction strong and strong with certain surface functional groups (Chen et al., 2019)

\subsection{Prediction of the release duration}

The prediction could be achieved by fitting the data shown in Figure 4 and 5 to the equation. Referring to the curvature in the linear axis form, fitting process applied $y=a \exp ^{-b x}$ equation, in which the fitting parameters data are shown in Table 3. Once the fitting parameters obtained, the data were used to estimate the day of which the leaching solution do not contain any fertilizer anymore, or said to be having nearly zero concentration in y axis. 
Table 3. Fitting Parameter of the evolution of concentration of leaching solution with time (in days) or the number of washing cycles.

\begin{tabular}{|c|c|c|c|c|}
\hline Sample & a & b & $\mathbf{r}^{2}$ & $\begin{array}{c}\mathbf{x} \\
\text { (Days) }\end{array}$ \\
\hline $\begin{array}{l}\text { Without } \\
\text { Biochar }\end{array}$ & 0,1833 & $-0,206$ & 0,8146 & 36,47 \\
\hline \multicolumn{5}{|c|}{ Influence of biochar size } \\
\hline $0,925 \mathrm{~mm}$ & 0,0992 & $-0,124$ & 0,811 & 55,64 \\
\hline $0,725 \mathrm{~mm}$ & 0,0681 & $-0,085$ & 0,5529 & 76,75 \\
\hline $0,4485 \mathrm{~mm}$ & 0,0548 & $-0,069$ & 0,5895 & 91,39 \\
\hline $0,2735 \mathrm{~mm}$ & 0,0459 & $-0,051$ & 0,8495 & 120,18 \\
\hline \multicolumn{5}{|c|}{ Effect of chemical activation and its concentration } \\
\hline $\begin{array}{l}\mathrm{HCl} \mathrm{3 \% 0,725} \\
\mathrm{mm}\end{array}$ & 0,037 & $-0,055$ & 0,5481 & 107,52 \\
\hline $\begin{array}{l}\mathrm{HCl} \mathrm{9 \% 0,725} \\
\mathrm{mm}\end{array}$ & 0,0282 & $-0,015$ & 0,1594 & 376,13 \\
\hline $\begin{array}{l}\mathrm{HCl} 15 \% 0,725 \\
\mathrm{~mm}\end{array}$ & 0,0321 & $-0,023$ & 0,2158 & 232,48 \\
\hline
\end{tabular}

Based on the estimated release duration, it is obvious that the use of biochar physically or chemically activated can hold better the fertilizer after sequential washing. While studying the influence of size, biochar at $0.2735 \mathrm{~mm}$ is estimated to be able to release the fertilizer with the longest duration, up to 120 days. As such, the influence of biochar size seems to play role, where the smaller the biochar, the longer the release duration. The chemical activation also seem to exhibit further the slower release mechanism, despite the requirement of some more data replication. Additionally, it has to be noted that the slower the release rate means the smaller quantity of nutrients being release over the time of investigation and does not necessarily in line with the plant nutrient requirement. Further investigation is required to validate the efficacy of such methods.

\section{Conclusion}

This investigation aims to study the influence of rice husk biochar size and the effect chemical activation on the release of fertilizer. Based on the analysis result, it can be reported that the presence of biochar is able to inhibit the dissolution of fertilizers. Moreover, this has been shown that both physical (by means of thermal involvement) and chemical activation play role for such purpose. Smaller size of biochar tends to positively affect the slow release process, due to the greater approximated pore surface area and volume extension. Such phenomenon is supported by previously shown data where smaller degree of inclination (in logarithmic axis) is shown for smaller size biochar. The use $\mathrm{HCl}$ as chemical agent to chemically activate biochar also exhibit positive results as shown by the longer estimated release duration than any other treatments applied upon this investigation.

Therefore, this research project is able to turn biochar, initially considered as agricultural waste, into a potential product. The addition of biochar as a medium to delay the release of fertilizer has been shown to reduce the rate of nutrient release through the observed absorbance data. The addition of chemical activators in biochar is better at holding the release of fertilizer compared to biochar, only activated by physical means.

\section{References}

Ademiluyi, F. T. \& David-West, E. O., 2012, Effect of chemical activation on the adsorption of heavy metals using activated carbons from waste materials. International Scholarly Research Network ISRN Chemical Engineering Volume 2012, Article ID 674209, 5 https://doi.org/10.5402/2012/674209

Chen, L., Chen, Q., Rao, P., Yan, L., Shakib, A., \& Shen, G., 2018, Formulating and optimizing a novel biochar-based fertilizer for simultaneous slow-release of nitrogen and immobilization of cadmium. Sustainability (Switzerland),Vol.10 No.8 .https://doi.org/10.3390/su10082740

Chen, Ruofei, Liqing, L., Zeng, L., Mingming, L., Chunhao, W., Hailong, L., Weiwu, M., \& Shaobin, W., 2017, Preparation and characterization of activated carbons from tobacco stem by chemical activation, Journal of the Air \& Waste Management Association, Vol. 67 No.6, April:713-724 https://doi.org/10.1080/10962247.2017.1280560

Chen, R., Zhao, X., Jiao, J., Li, Y., \& Wei, M., 2019, Surface-Modified Biochar with Polydentate Binding Sites for the Removal of Cadmium. International Journal Molecular Sciences.Vol.20 No 7, April: 1775. DOI: $10.3390 / \mathrm{ijms} 20071775$

El-Hendawy A-NA., 2009, An insight into the $\mathrm{KOH}$ activation mechanism through the production of microporous activated carbon for the removal of $\mathrm{Pb}^{2+}$ cations. Appl Surf Sci 2009; 255: 3723-3730.

Fengfeng, M., Baowei, Z., Bin, L., 2015, Adsorption characteristics of ammonium onto biochar derived form corn straw, J. Journal of LanZhou Jiaotong University. 34(1) (2015) 125-132

Glaser, B., Wiedner, K., Seelig, S., Schmidt, H. P., \& Gerber, H., 2015, Biochar organic fertilizers from natural resources as substitute for mineral fertilizers. Agronomy for Sustainable Development, Vol. 35 No.2: 667-678. https://doi.org/10.1007/s13593-014-0251-4

Grycová, B., Koutník, I., Pryszcz, A., \& Kaloč, M., 2016, Application of pyrolysis process in processing of mixed food wastes. Polish Journal of Chemical Technology, Vol. 18 No.1, 19-23. https://doi.org/10.1515/pjct-2016$\underline{0004}$

Indarto, A. \& Hartanto, Y., 2019, Penentuan model adsorpsi metil merah pada karbon aktif berbasis torefaksi arang batubara. Indonesian Journal of Chemical Research. https://doi.org/10.30598//ijcr.2019.7-ind

Li, W., L. Zhang, J. Peng, N. Li, and X. Zhu., 2008, Preparation of high surface area activated carbons from tobacco stems with $\mathrm{K}_{2} \mathrm{CO}_{3}$ activation using microwave radiation. Ind. Crops Prod. Vol. 27 No.3:341-7. https://doi.org/10.1016/j.indcrop.2007.11.011 
Peiyu, L., Luping, X., Hui, X., Wen, X., 2016, Research of Adsorption on PCBs : Isoterm Modelling and Influencing Factors. MATEC Web of Conferences 67. https://doi.org/10.1051/matecconf/20166706030

Nair V, Vinu R., 2016, Peroxide-assisted microwave activation of pyrolysis char for adsorption of dyes from wastewater. Bioresour Technol, Vol. 216: 511-519.

Sizmur, T., Fresno, T., Akgül, G., Frost, H., Moreno Jiménez, E., 2017, Biochar modification to enhance sorption of inorganics from water, Bioresource Technology, doi:

http://dx.doi.org/10.1016/j.biortech.2017.07.082
Tan, X., Liu, Y., Gu, Y., Liu, S., Zeng, G., Cai, X., Hu, X., Wang, H., Liu, S., and Jiang L., 2016, Biochar Pyrolyzed from MgAl-layered Double Hydroxides Pre-coated Ramie Biomass (Boehmeria niveria(L/) Gaud): Characterization and Application for Crystal Violet Removal. Journal of Environment Management, Vol.184 : 85-93.

Zhong, X., Wang, M., and Jiang, E., 2018, Preparation of an environment-friendly biochar fertilizer. IOP Conference Series: Materials Science and Engineering, Vol. 301 No. 1 .https://doi.org/10.1088/1757899X/301/1/012157 